\title{
A fogyókúrák buktatói - pszichés tényezők
}

\author{
Resch Mária dr.
}

Mottó: A leghatásosabb diéta mindig észrevétlen.

\begin{abstract}
Bevezetés: Az evés az egyik legalapvetőbb örömforrás. A különböző fogyókúrák ettől az élvezettől fosztanának meg úgy, hogy közben korántsem garantálnak helyette mást, például egy életre szóló helyes táplálkozási magatartást, vagy tartós megoldást a túlsúlyproblémákra. Célkitüzés: A jelen tanulmány céljaként azokat a pszichodinamikai összefüggéseket tárja fel, amelyek valamennyi diéta, fogyókúra sikertelensége mögött állhatnak. Módszer: Az elhízás, a kövérség, valamint a fogyókúrák sikertelenségének a kognitív viselkedésterápiás szemlélettel történő elemzése. Eredmények: A kognitív viselkedésterápiában igazolt, lefektetett törvényszerúségek alkalmazásával rálelhetünk azokra a konkrét, fogyókúrázási-hízási folyamatokban levő etológiai okszerúségekre, amelyek a gyógyító tünet-, illetve problémaorientált pszichoterápia során sikeresen felhasználhatók. Következtetés: Összességében megállapítható, hogy javasolt lassan, kis lépésekben haladni a kitűzött cél felé. Tanulásos módszerekkel a környezet folyamatos átalakítása közben az obes egyén a saját nemkívánatos viselkedési attitúdjeit levetve újakat építhet ki, számára kívánatos szokásokká formálhatja, miközben a személyisége is csiszolódik. Orv. Hetil., 2017, 158(13), 499-507.
\end{abstract}

Kulcsszavak: kövérség, evészavarok, fogyókúra, kognitív viselkedésterápia

\section{Dieting pitfalls - psychological factors}

\begin{abstract}
Introduction: Eating is one of the fundamental sources of happiness. Slimming diets would deprive you of this very enjoyment without granting something else instead, for example, proper eating behaviours for life or a permanent solution for overweight-related problems. Aim: This paper aims to investigate the psycho-dynamic relationships that might be the reason for the failure of all diets and slimming diets. Method: Analysing overweight, obesity and the failure of slimming diets with the help of the cognitive behavioral therapeutic approach. Results: By applying the principles confirmed and laid down by the cognitive behavioral therapy, we can identify specific ethological causes present in dieting and gaining weight behaviours that can successfully be used in curative symptom and problem oriented psychotherapy. Conclusion: In summary it can be stated that it is advised to approach the defined objective slowly, in small steps. With the help of learning methods and the continual transformation of the environment, obese individuals, having shred their own unwanted behavioral attitudes, can not only build up new attitudes and transform them into new desirable habits but will also have their personalities chiselled.
\end{abstract}

Keywords: obesity, eating disorders, slimming diet, cognitive behavioral therapy

Resch, M. [Dieting pitfalls - psychological factors]. Orv. Hetil., 2017, 158(13), 499-507.

(Beérkezett: 2016. december 13.; elfogadva: 2017. február 4.)

\section{Rövidítések}

$\mathrm{ADHD}=$ (attention-deficit hyperactivity disorder) figyelemhiányos hiperaktivitás; $\mathrm{CBT}=$ (cognitive behavioral therapy) kognitív viselkedésterápia

Az evés az egyik legfontosabb örömforrás. Az ember születésétől fogva szereti ingerelni a száját, ugyanis a fokozott orális aktivitás - túl a vegetatív funkciók ellátá- sán - pozitív archaikus jelentőséggel bír. A csecsemő korai tapasztalatainak nagy része az evés-táplálás élményéből fakad. Az evés-etetés során nem csupán jóllakik, hanem társas viszonyt is tanul, az ételt azonosítja a szeretet, az öröm, a kielégülés és a védettség érzésével $[1,2]$. Azoknál, akiknél a száj alapvető szerephez jut, ott ezek a korai elsődleges élmények alapozzák meg a magasabb fokú érzelmeket, és minden felnőttkori tapasztalat, tanulás ezekkel lesz kapcsolatba hozható [2, 3]. A száj, az 
ajkak gazdagok idegvégződésekben, aminek az ingerlése örömszerzéshez, szorongásoldáshoz vezet. Így lehet, hogy a cigarettázás, pipázás, rágózás, nassolás, de a folyamatos beszéd is feszültségoldó hatással bír. A dohányzásról leszokáskor sokan „pótcselekvésként” rágcsálni, nassolni kezdenek, ami súlygyarapodáshoz vezethet, és ezáltal fokozza az önértékelési problémákat, a szorongást, ami újabb kilókat és elhízást jelenthet [4-6]. A csökkent önértékelés, az elutasítástól való félelem és az interperszonális kapcsolatokban (például: képzés, munkahely) fellépő elő́téletesség, negatív diszkrimináció pedig olyan megbélyegzéshez vezethet, amely a hagyományos empatikus attitűddel nem orvosolható. A német elhízottak 23,5\%-a teljes egészében, 55\%-a pedig részben azonosul a megbélyegző beállítódásokkal. A megkérdezettek mindössze 21,5\%-a nem mutat semmiféle hajlamot a testsúlyhoz kapcsolódó negatív beállítódásokra, a stigmatizációra [7]. Hilbert és mtsai a kövéreket olyan speciális csoportba tartozóknak tartják, ahol a stigmatizációval járó pszichés változások kezelése a kognitív és viselkedésterápiás módszerekkel valósítható meg [7].

Tehát a korai anyagfelvétel folyamatának a sérülése nyomot hagyhat a személyiségben, különösképpen a táplálkozási szokások, a szexuális viselkedés, a szociális kapcsolódási készség, valamint a szorongásra vagy az örömképességre való hajlam területén [2-6, 8].

A viselkedési tanuláselméletben alapvető szervezőeró a jutalom (például zsetontechnikák), ami többnyire szintén egy falat étel. Az egyik leggyakoribb hiba az étel nevelési eszközzé degradálódása [5].

Köztudott, hogy az evés-fogyás harcában, a sikertelen fogyókúrák hátterében pszichés tényezők játszanak szerepet. A szájimádat, az ételek elutasítása pedig sohasem egyetlen lelki okra vezethető vissza. Az étkezési szokásokat ugyanis sokkal inkább az aktuális érzelem, az adott lelkiállapot és az egyéb lényegtelennek tûnő külső tényezők vezérlik, semmint a fiziológiai éhségérzet [5-8]. Főként ezek a faktorok lapulhatnak meg azon kérdések eldöntése mögött is, hogy valaki mit, mikor és mennyit eszik. Táplálkozáskutatók azt találták, hogy az emberek naponta legalább 200, az étkezéssel kapcsolatos döntést hoznak, amelyek jelentős része tudattalan [9]. Nem csoda, hiszen az emberek többségének gyakorta már ébredéskor a reggelin vagy a kávéhoz bekapott falatokon járnak a gondolatai.

A tanulmány a fogyókúrák sikertelenségét, a permanensen fennálló vagy éppen mindig visszatérő kövérség háttérokait a kognitív és viselkedésterápiás törvényszerúségek segítségével veszi sorra. A lényege, hogy a fogyókúrák kudarcai mögött fellelhető diszfunkcionális gondolkodás és a téves, maladaptív viselkedésformák felismerése a kognitív viselkedésterápia (cognitive behavioral therapy - CBT) tanuláselméleti törvényszerüségeinek felhasználásával történik [10]. (Megjegyzendő, hogy az alapvető elvek, elméletek ismertetése a jelen tanulmány kereteit messzemenően meghaladnák, másrészt számos pszichoterápiás tankönyvben megtalálhatók
[11].) Ennek érdekében a kognitív terápia eszközeivel a terapeuta azonosítja mindazokat a diszfunkcionális attitûdöket, hiedelmeket, félelmeket fenntartó gondolkodási-logikai hibákat, nem adaptív viselkedésformákat, amelyek a hízás-fogyás dinamikája köré rakódnak és megakadályozzák a súlycsökkentésben a tartós eredmény elérését, illetve a hosszú távon való megtartását.

A viselkedésterápiával az egyén és a szúkebb-tágabb környezete közötti interakciók során keletkezett zavarok felismerése a cél, mert a gyógyítás során majd ezeket kell megváltoztatni úgy, hogy az illető számára kedvezőbb magatartásformák léphessenek helyébe $[11,12]$.

Jelen tanulmány fogalomhasználatában a diéta egy olyan speciálisan összeállított étrend, ami nem kifejezetten a fogyást célozza, ilyenek például savanyító/lúgosító, laktózmentes, gluténmentes, purinban szegény diéták. A fogyókúra pedig egy olyan időben behatárolt gyógyítóeljárás, amelynek az egyedüli és legfőbb célja a testsúlycsökkenés. Így csak az obesitas és a súlycsökkentő manőverek, fogyókúrák kudarcai mögött álló oki tényezőket, tehát ezek etológiáját veszi sorra kognitív-viselkedésterápiás szemmel.

Természetszerúleg az egyik legfontosabb konklúzió a kognitív és viselkedésterápiás módszerek alkalmazásán keresztüli gyógyítás, amelynek részletes taglalása azonban nem cél és egyébként is meghaladná a jelen tanulmány kereteit, ezért erre részletesen nem tér ki. Szintén terjedelmi okok miatt a tanulmány nem összehasonlító jellegű, tehát nem vizsgálja más pszichoterápiás módszerek, társadalomtudományi alapelvek hatékonyságát a témában [10-12].

\section{A fogyókúrák kudarcai mögött álló általános pszichés tényezők}

Általánosságban elmondható, hogy a különböző korlátozó fogyókúrák (például zsírszegény, kalóriaszegény, rizsdiéta, gyümölcsdiéta) két dologban azonosak: 1 . meghatározott ideig korlátozzák valaminek a bevitelét, és 2. mértéktelenül megengednek minden mást. Tudni kell, hogy minden korlátozó, egyhangú étrend a tápanyagok és vitaminok megvonásával jár. Mindegy, milyen diétát választottak vagy választanak a fogyni vágyók, semelyik sem jelent megoldást a problémára. Nem tanít meg semmire, csak a koplalás és az egyhangú étkezés elviselésére, és amint visszatér a fogyókúrázó a túlsúlyt eredményező helytelen étkezési szokásaihoz, életmódjához, a lekoplalt kilók akár duplán is visszarakódnak (jojó effektus).

- A fogyókúrában a kedvenc ételek elhagyása nem javasolt, mert a tudatosan és folyamatosan (még ha csak konkrét időre szólóan is) megvont ételek egyre inkább hiányozni fognak. Ott kísértenek a mindennapok gondolataiban, és mint „tiltott gyümölcs” egyre kívánatosabbakká válnak. Ez a fogyókúra biztos kudarcához vezető út. Viszont, ha nincsenek tabuk, a „kvázi” fogyókúra során is mindent lehet enni, akkor könnyebb 
elfogadni, hogy ez az újratanult táplálkozási magatartás egy életre szól [10].

- A fogyókúrák másik beugratója hogy „turbo” fokozattal, azonnali eredménnyel kecsegtetnek. A sikertelenség másik leggyakoribb oka ez. Ugyanis, bár csak rövid távra, mégis olyan mértékű kalóriamegvonásra invitálnak, amit csak nagy szenvedések árán sikerül betartani. Tévhit, hogy nem érezhető az éhség. Sőt egy bizonyos fokon már fájdalmat okozhat. Közismert, hogy az anorexia nervosa kialakulásának kezdeteiben még erős az éhségérzet. Sokan rendkívüli fájdalmakról és kínokról számolnak be. Elmondásuk szerint „pokolian nehéz" túllendülniük ezen, s eljutni oda, amikor már nem éreztek semmit [10, 13-16]. A genetikai adottságnak, testalkatnak, kornak megfelelő mennyiségú táplálékbevitel esetén megtapasztalható, hogy nem kell lemondani semmiről, tehát minden ehető, csak kisebb mértékben. Így szinte észrevétlenül napi 100200 kcal-val kevesebb jut a szervezetbe, ami még nem okoz sem fizikai, sem érzelmi szenvedést. Wansink észrevétlen zónának nevezi ezt [9, 14, 17].

Fontos azt is megjegyezni, hogy a napi $100 \mathrm{kcal} \mathrm{mí-}$ nusz csak hosszú hónapok, évek (egy év alatt 4-5 kg) alatt hozza meg a várt eredményt. Viszont ez idő alatt már a mindennapok részévé válhat az új viselkedési minta. Megtanulható, hogyan lehet a kevesebbel jóllakni és hogyan kell figyelni a környezet manipulatív kihívásaira, valamint a nyilvános megbélyegzés és a saját bűntudatból, inkompetencia érzéséből fakadó önértékelési zavarok, szorongás, depressziós tünetek helyes kezelésére [7].

\section{A fogyókúrák kudarcaiban szerepet játszó konkrét pszichés tényezők}

Nem jól körülhatárolt az éhség vagy a jóllakottság érzete, mert azt a környezeti és a testből jövő ingerek, vagyis az aktuális lelkiállapot felülírhatják. (Például gondoljunk egy karácsony esti vacsorára vagy egy születésnapi bulira, amikor a vendégek már minden fogást végigettek és minden finomságot megkóstoltak, azt hinnénk, hogy ennél többet nem képesek enni. S akkor jön a nagy fogás, aminek nem lehet ellenállni, amit nem illik visszautasítani.)

Sok olyan, a kognitív kontrollt befolyásoló hatás vesz észrevétlenül körül, amelyek komoly szerepet kapnak a túlsúly kialakulásában, a fogyókúrák kudarcában. A pszichológiában környezeti noxáknak vagy toxikus környezetnek nevezik ezt $[9,17,18]$. A kérdés, hogy valóban noxáról, ártalomról van-e szó? Lehet, hogy ezek a környezeti hatások nem külsők, hanem belső pszichés tulajdonságok? Nézzük, miről van szó!

1. Általánosságban elmondható, hogy nem azok a sikeresek a testsúly megtartásában, akik folyamatosan ellenállnak a kísértésnek, hanem akik elkerülik azt. „Eszem, ha látom." Amit az ember nem lát, az nincs, de legalábbis nem jut az eszébe, nem gondol rá.
Egy svédasztalos kongresszusi fogadásnál az bizonyosan többet eszik, aki a csábító, dúsan megrakott, finomságoktól roskadozó asztalokkal szemben foglal helyet. Míg eszik, aközben is rátéved a szeme a húsok és köretek, a saláták kínálkozó világára, és már el is határozza, hogy ezekből is kóstol [9].

A viselkedésterápiás elmélet ezt a jelenséget rábangolódásnak nevezi. A tanuláselmélet törvényszerúsége szerint a ráhangolódás egyfajta helykészités az új számára. Előkészítése az előzetes ismeretek, a tudásanyag azon területének, ahová az újonnan szerzett ismeret majd beilleszkedik. A jelentésteremtés fogja az előzetes ismeretek szerinti pontos helyére illeszteni. Így keletkezik a rendszerszemléletü, kritikai gondolkodás. Az új ismeret természetesen nem passzívan ül a többi között, hanem hatást gyakorol rá, átértékel. A reflektálás aktívan alakítja a gondolkodást, viselkedést. (A fenti példa viselkedéselméletileg úgy néz ki, hogy látva a széles kínálatot, nemcsak a leves, hanem az újfajta sültek és köretek számára is helykészítés zajlik, miközben már tervben van a sütemények és gyümölcsök bevitele is.)

2. A fentiekkel függ össze a Rolls és mtsai által igazolt megállapítás, miszerint a nagyobb választék növeli a fogyasztás mértékét [18]. Kísérletük szerint a vizsgált személyeknek három különböző joghurtot kínálva 23\%-kal nagyobb volt a fogyasztás ahhoz képest, mintha azok csak egyfélét választhattak volna. Kabn és mtsa kimutatták, hogy a vizsgált személyek nemcsak akkor ettek többet, ha nagyobb volt a választék, hanem akkor is, ha csak azt hitték, hogy az [19].

Közismert tény, hogy mindig az első falatot érezzük a legízletesebbnek. A háziasszony folyamatosan kóstolgatja a húslevest, és a végén már maga sem tudja, hogy sós vagy sótlan. Ez példa az ingerspecifikus telitődésre, aminek a hátterében az a tudományos tény áll, hogy az érzékszervek, az ízlelő- és szaglószervek habituálódnak, ha folyamatosan ugyanaz az inger éri őket. Azok a repetitív ingerek, amelyek hatása közömbös a recipiensre nézve, egyre kisebb választ váltanak ki, míg végül egy idő után a válaszreakció teljesen elmarad. Élettani jelentősége, hogy az ember elkerülhesse a számára közömbös ingerekre adott válaszokat, miáltal energiát takaríthat meg [11].

A fenti kísérleti példákban tehát minél változatosabb ingerek érik az érzékszerveket, annál hosszabb idő jut azok habituációjára. Így hosszabb ideig, nagyobb mértékben lehet fogyasztani, ami hízáshoz vezethet.

3. Egy illat, egy íz elegendő lehet, hogy ne érezzünk mardosó éhséget, ezért a craving leküzdésére is szolgálhat. Egy anorexiás nőbeteg nagyon szerette az édességet. Egyik alkalommal arra a szokásos kérdésre, hogy sorolja, mit evett aznap, büszkén és boldogan mondta, hogy már ropit, csokit és cukorkát is nassolt. Hogyan? Reggel és este egy szál ropi mellé a felvágott csokoládétáblából egy kis gerezdet majszolt és délután egy szem cukorkát nyalogatott hozzá. Így maradt belőle másnapra is $[14,15,20,21]$. 
A modellek világában gyakran találkozhatunk olyan történetekkel, hogy a kívánt édességet vagy csak szagolgatják, vagy beleharapdálnak, rágogatják, de végül kiköpik. Nemritkán pedig az eltett kedvenc csoki, cukorka papírját szippantgatják, legyưrve az adott édesség iránti vágyat. Ahhoz, hogy a háttérben zajló kognitív folyamat érthető legyen, nézzük sorra az alábbi ismereteket: A feltétlen reflex velünk született, akarattól függetlenül múködik, az adott konkrét inger hatására automatikusan, azaz feltételek nélkül kiváltódik. Például az édességbe harapva azonnal kiváltódik a nyálelválasztás. A feltételes reflexek akarattól függőek, és tanulás révén alakulnak ki. Például egy csokoládépapír vagy a cukorka zacskója természetesen mindig a kedvenc édességhez kapcsolt, tehát annak a látványa vagy az illata már elegendő, hogy beindítsa a nyálelválasztást. A két inger időbeni érintkezése (az édesség kihámozása és a szájba juttatása), azaz kontiguitása jó, hiszen közöttük általában kevesebb mint fél perc telik el. Az általánosítás (generalizáció) fogalmán keresztül érthetjük meg azt, hogy ugyanahhoz a finomsághoz kapcsolt szín, illat, egyéb jellegzetesség ugyanúgy kiválthatja a nyálelválasztást, azaz beindíthatja a feltételes reflexet. Tehát a kondicionálás során egy adott ingerre kiépült feltételes válasz, más az adott ingerhez hasonló ingerekre is megjelenik [11, 20-23].

Ha a feltételes ingerrel együtt megjelenő inger megkapja annak kiváltó-jelző értékét, aminek következtében egymaga is képes lesz a feltételes válasz kiváltására, akkor a fent leírt klasszikus kondicionálás hatóterülete megnövekedhet. Ez a folyamat a másodlagos kondicionálás. (Például a pékség előtt elsétálva frissen sült cipók és kalácsok illata árad, amire összefut a szánkban a nyál és kicsi a valószínüsége, hogy ne csábuljunk be valami finomságra.) Nemcsak az ízleléssel, hanem a szaglással is szoros korrelációban áll az éhségérzet. Az ismerős illat kiváltja a nyálelválasztást és az éhségérzetet, ugyanis a táplálék bevitele jelenti a megerősítést. Megjegyzendő, hogy abban az esetben, ha rendszeresen nem jelenne meg a feltétlen inger, azaz a táplálékbevitel, a feltételes válasz kioltódik, vagyis a tanult válasz gátlás alá kerül. Ez az újabb példa még egy fontos különbségre mutat rá: a „becsábulás” már az egyén cselekménye lesz. S a saját viselkedésének a következményeit tanulja meg (operánskondicionálás), ha sokszor betér kalácsot enni, akkor egyrészt az éhsége csillapodik, megerősítést kap a feltételes reflex, de másrészt fokozatosan elhízik. Egy alapvető biológiai szükséglet kielégítését (mint például az éhség esetén a kalács) elsödleges megerösitésnek nevezzük. A másodlagos megerösités pedig olyan érzékszervi inger (például szag, íz, látvány), amely az elsődleges ingerrel egy időben vagy röviddel előtte jelenik meg és így a tanulást segíti elő (például a cipók illata). Tehát ugyanazt a feltételes reflexet (a nyálcsorgással és a teltségérzéssel) váltja ki a cipók illata vagy látványa, mintha valóban megízlelnénk, ső́t le is nyelnénk. Természetesen az így szerzett tapasztalatok kognitív lenyomatot adnak, ennélfogva nem kell minden egyes alkalommal újratanulni ezt $[11,15,21-23]$.
Megjegyzendő, hogy bár az evészavaroknak létezik addiktív modellje, a fent leírt jelenség mégsem teljesen ugyanazon pszichológiai és szomatikus háttérrel igazolható. A fent részletezett hasonlóság tetten érhető például a drogos szerhasználatában a megszokott eszközeivel, a megszokott helyen vagy a dohányos sokszor ismételt rítusaiban. Viszont lényegesek a különbségek: Míg például az alkohol, drog esetében a craving esetén is a „soha egy nyalást sem" elv múködik a visszaesés, a kontrollvesztés elkerülése érdekében, az evés esetén erről nincsen szó. A másik fontos eltérés, hogy míg például az alkoholdependenciában kontraindikált a kis lépésekben elhagyás, tehát rögtön abbahagyva az italfogyasztást a mellékhatást kezelik, addig a benzodiazepinfüggőségben (vagy a fokozatos fogyasztás módszerében is) apró kis lépésekben veszik el a szert. Ennek további taglalására a hely hiánya miatt nincs lehetőség, és a közleménynek nem célja.

4. A tányéron lévő étel kinézete, nagysága befolyásolja, milyen fokú jóllakottságot, teltséget vár el tóle az ember. A kutatók ezt elvárt jóllakottságnak nevezték. A jóllakottság érzésére és időbeli tartósságára vonatkozó elvárásokat mindenki az élete során elfogyasztott több tízezer étel alapján állítja fel. Ha nem állnak rendelkezésre korábbi tapasztalatok - a kutatások szerint -, a legtöbben hajlamosak attól tartani, hogy az újonnan megismert ételtől nem fognak jóllakni [9].

A háttérben a már ismert és fent leírt folyamat állhat: Az étkezések során nem grammokat és kalóriákat eszünk, hanem egy tányér levest, egy szelet pizzát és így tovább. Ezen ételek a mindennapjainkban mindig ugyanúgy jelennek meg, tehát ezekhez a külső ingerekhez, mint illat, látvány kapcsolódik a feltételes reflex, a teltségérzet. Az észlelések során ezekről az ételekről, fogásokról engramok (lenyomatok) keletkeznek, amelyek kódolás után bevésődnek a tudatba azért, hogy tárolhatók lehessenek. Erre azért van szükség, hogy a későbbiekben egy hasonló inger előhívhassa az egész lenyomatot. Például, aki megismeri a bablevest, annak ízét, képét és a megevését követő jóllakottság fokát, akkor a későbbiekben, ha egy étlapon a bablevest látja, előhívódik a hozzá kapcsolt illat-, ízvilág, és a konkrét jóllakottság érzése, amit elvár. Érdemes elgondolkodni azon, hogyha az adott fogáshoz tartozó kalóriát társítanák, akkor az egészségtudatos emberek nem a látvány, hanem a kiírt kalória alapján választanának és azt tanulnák meg $[11,24]$.

5. Az étkezések során nemcsak a látvány lehet csalóka, hanem az ízek változatos világa is. (Például, ha egy banán nem banánosan néz ki, akkor az ízét sem banánnak érezzük. Már a megnevezés is fontos: amikor azt mondom, milyen finom banános íze van a túrónak, akkor azt is fogom érezni, még ha nem is az van benne, hanem valami más. Gyakran találkozunk ezzel a jelenséggel a mindennapokban is: Egy háziasszony már elöre cuppogtatva dicsérgeti vendégeinek a föztjét, főként akkor, ha nem sikerült annyira, vagy a vőfély népies rigmusokba szedve vicces strófákkal hoz nagyobb kedvet a lakodalmi 
ételekhez.) Az olvasott szövegek is a látványhoz tartoznak, mindig többre engednek következtetni, mint ami a valóság, fogyasztásra csábítanak. (Például: Ön melyiket választaná? A halikrát vagy a kaviárt? A csokoládés süteményt vagy a dupla csokis svájci Fekete-erdő tortát? $\mathrm{Az}$ étel egyik esetben sem változott, csupán a neve lett flancosabb.) Ez mégis komolyan befolyásolhatja a választást, sőt azt is, hogy mennyire fogjuk ízletesnek találni. (Az étlapok titokzatos, leleményes elnevezései nemcsak márkanevekben, hanem a nosztalgikus elemekben [nagyi nudlijával] vagy híres földrajzi helyekben [óvári sertésborda] is gazdagok. S ha még ez sem elég, akkor az érzékszervekre apelláló kellemes hangulatot keltő szavakat [bársonyos eperízzel öntött omlós vajas tészta] hívnak segítségül.) Ezt a jelenséget nevezzük várakozási (expectation assimilation) vagy megerósitési torzitásnak (confirmation bias) $[9,18,23,24]$. A világ minden dolgáról, így a banánról is mentális reprezentáció készül, amely őrzi a banán jellegzetes ízét, alakját stb., és a későbbiekben ezeken a reprezentációkon hajtunk végre kognitív múveleteket. A túró mentális reprezentációjában annak a sajátos íze is benne foglaltatik. Amennyiben folyamatosan ezzel a jellegzetes ízzel történik a megerősítés (= az adott válasz megjelenési valószínűségét növelő esemény, jel), a banán mentális reprezentációjában teljes hasonulás, azaz asszimiláció megy végbe.

Ugyanez áll a következők mögött: Sokan a korábbi tapasztalatok megerősítése kapcsán azt gondolják, hogy a márkás termékek azért drágábbak, mert azok minőségileg jobbak. S mivel ezt gondolják, a tapasztalataik is általában kedvezőbbek. Ez a pozitív elvárás a termékkel kapcsolatban nemcsak a márkanév varázsának köszönhető, hanem a magasabb ár, a nehezebb elérhetőség, a termékek csomagolása és reklámszlogenek, képek egyaránt hozzájárulnak. Tehát becsaphatnak a saját tapasztalatok. A feltételes reflex (operáns kondicionálás), ha sokáig nem kap megerósítést (= negatív megerösités), akkor egy idő után kioltódik és elmarad a (feltételes) várt válasz. Vagyis, ha több alkalommal az elvárttal ellenkezőt tapasztaljuk, akkor felülírjuk a korábbi márkahűséget, a megelőző kedvencet [24].

\section{A fogyókúrák kudarcaiban szerepló személyiségi tényezők}

1. A túlsúly egyik előrejelzője lehet az impulzivitás. Wansink megfigyelései szerint azok, akik az impulzivitásskála felső 10\%-ába estek, átlagosan 10 kilóval voltak nehezebbek a skála ellenkező pólusába tartozóknál [9].

A szervezetnek körülbelül 20 perc kell a telítettségérzés kialakításához, vagyis minimum ennyi idő múlva jön rá egy habzsoló ember, hogy tele van, nem bír többet enni. Ez alatt viszont óriási adagokat lehet betömni. A bulimiában szenvedők bingei mögött is fellelhető ez a mozzanat: ízek érzése nélkül, szinte meg sem rágva küldik a gyomrukba a falatokat, hogy minél inkább elérjék a telítő, feszítő érzést $[9,13-15,25,26]$. Vegyük észre, hogy az impulzivitás, az indulatok, késztetések kontrolljának a zavara az egyik meghatározó jellemzője az evészavarok közül a bulimia nervosának és az anorexia nervosa purgációval járó altípusának. Egyébként ez a szimptóma még a diszruptív, impulzuskontroll- és viselkedészavarok csoporthoz tartozó kórképekben, a borderline személyiségzavarban is megfigyelhető. Vezető tünete a figyelemhiányos hiperaktivitás (attentiondeficit hyperactivity disorder - ADHD) betegségnek, és előfordulhat még több más pszichiátriai kórképben, így például a bipolaritásban [13-15, 27]. Az evészavarban szenvedők önszabályozó rendszere - tehát az a képességük, amely lehetővé teszi, hogy a saját belső testi-lelki állapotaikat, az impulzusaikat, késztetéseiket és a szükséges eróforrásaikat kezelni tudják - sérült. Természetesen a jó múködés feltételezi az előbbiek ismeretén túl még a saját preferenciák és az intuíciók tudását is. Ez az éntudatosság [11].

2. Bármi, ami elvonja a figyelmet az ételrôl, az étkezésrôl növeli annak a valószínúségét, hogy a táplálkozás kontroll nélkülivé válik. (Mindenki tapasztalta, hogy a tévénézés vagy a mozizás alatt eszegetett pattogatott kukorica, csokoládé és cukorka mennyisége óriási méreteket ölthet. S ha mindezt magányosan, az ölbe tett tál nassolnivalóval tesszük, akkor ez a birtoklási vágy kiélésére is lehetőséget nyújt.) Az impulzivitás egyik jellemzője a kontrollvesztés. Amennyiben ez a táplálkozási viselkedéshez kapcsolt, akkor ez azt jelenti, hogy az illető túlságosan sokat eszik vagy iszik, és egyszerűen nem bírja megállítani a cselekedetét, elmegy a végsőkig. Az önmagát hátráltató impulzusok és affektusok kordában tartása, azaz az önkontroll ebben az esetben insufficiens [11].

3. Társaságban hajlamosabbak vagyunk többet enni. Egyrészt, mert a másikat figyelve senki sem akar „kilógni a sorból”. Másrészt, a szorongás is megehető: „Amíg eszem, nem kell viselkednem.” A szorongó, elkeriülo személyiségtípusú ember szúk családi/baráti körben is többet ehet a kelleténél, mert „nem illik” nem fogyasztani, keveset enni. A kritikától, visszautasítástól vagy helytelenítéstől való félelme miatt ugyanis nehezebben nyilvánul meg, nem hoz önálló döntéseket, inkább az általános elvárásoknak megfelelően igyekszik cselekedni. Visszafogott, zárkózott, a megszégyenüléstől vagy a nevetségessé válástól való aggodalma miatt sztereotípiákban cselekszik és már automatikusan rág $[13,15]$. (Megoldás lehet a lassan, megfontoltan csipegetés, miközben a beszélgetés, a kortyolgatás is sokat segíthet abban, hogy oldódjon a belső feszültség, sikerüljön ellazulni, másrészt pedig legyen idő észlelni a belső proprioceptív ingert, a jóllakottságérzést.)

A köznapi értelemben vett érzelmi evők vagy a stressz, a feszültség miatt esznek többet, vagy amikor kedvetlenek, szomorúak, túlhajszoltak, mintegy jutalomként. A tudományos értelemben az első csoport az úgynevezett „stresszevők”, ahol a fokozott szénhidrátéhség részben a megnövekedett kortizolszinttel magyarázható 
$[6,10,26,28]$. A krónikus stressz hozzájárulhat a fogyókúrák betartását akadályozó magatartások, úgymint a rendszertelen étkezés, emocionális evés kialakulásához is. A második csoportba az emocionális alapon fellépő evészavarok tartoznak, valójában szakmailag ők tekinthetők érzelmi evőknek, amellyel viszont a következő bekezdés foglalkozik.

4. Mit kell tudni a vigaszfalatokról? Több kutatócsoport bizonyította, hogy a hangulat befolyásolja az étkezést, nemcsak azt, hogy mit és mennyit, hanem azt is, hogy mi módon. A várakozásokkal ellentétben szerintük az emberek nem annyira a bánatban, mint inkább az örömben nyúlnak a nassolnivalók után. Kísérleteik alapján mindezt kétszer olyan gyakran teszik boldogságukban, semmint bánatukban. Tehát nem annyira a vigasztaló-jutalmazó jelleg dominál, mint inkább az, hogy lélekmelengetó, simogató, kellemes érzéseket varázsoljon elő, mintegy megkoronázva az örömérzetet, ahol nem csak a test, hanem a „lélek is jóllakik” $[6,8,17$, 20-23]. (A férfiak lelkét inkább a házi koszttal - fóként, ha az a gyermekkoruk felhőtlen, boldog világát idézi lehet megfogni. A nőket ez csak az unalmas és fárasztó házimunkára emlékezteti, ezért ők is inkább olyan vigaszfalatokat keresnek, ami az eufória mellett a gondtalanság emlékeit idézi fel bennük.)

$\mathrm{Az}$ 1. táblázat segít annak eldöntésében, hogy valaki testileg vagy csak inkább érzelmileg éhes. A táblázat bemutatja a Helmering és mtsa által leírt idevonatkozó ismereteket a saját megfigyelésekkel kiegészítve [23].

$\mathrm{Az}$ élet mind teljesebb élvezetéhez a vigaszfalatok, a nasik is beletartoznak. A test és lélek harmóniájában nem árt, ha nemcsak egészséges, hanem élvezetes is a táplálék. Fontos, hogy a favorizált ételek sorrendje átprogramozható, áttanulható.

5. Egy étellel való első találkozás meghatározó lehet. Az adott körülmények és az ahhoz kapcsolódó érzések, élmények jelentős szerepet játszhatnak abban, hogy bizonyos fogások kedvencekké, jutalomfalatokká váljanak, vagy akár ellenkezőleg, az utálat-undor tárgyát képezzék [22]. Így alakul ki mindenkiben az ételek egyfajta rangsora. A felnőttként felvett új szokásokhoz, az egészségesebb ennivalókhoz kapcsolt örömhangulat, pozitív élmé- nyek - mint feltételes reflexek - a korábbi kedvencek rangsorát fokozatosan átalakíthatják.

Tapasztalatok szerint e téren kétféle személyiség létezik: 1. aki a számára legfinomabb falatokkal indítja az evést, és 2. aki megeszi a kevésbé ízleteseket, majd csak a végén majszolja el a számára legjobbakat. Ehhez kapcsolódik az a figyelemre méltó kérdés, hogy ha valaki több fogásból álló ételsort fogyaszt el, az elsố (az első tényező hatása, azaz elsöbbségi hatás [primacy effect]), vagy az utolsó (friss tényező hatása, azaz recencia hatás [recency effect]) fogás lesz a meghatározó az egészről szóló véleménye kialakításakor. A megfigyelések szerint ez a korai tapasztalatok függvénye, ahol az egyik befolyásoló tényező az lehet, hogy sokgyermekes családban utolsóként nőtt fel az illető, vagy egykeként mindent egyszerre, azonnal megkaphatott [29-32].

Egyfajta magyarázatként szolgálnak erre a Guillaume és Gorwood által megfigyeltek. Gorwood a jutalomfüggo"séggel kapcsolatban végzett kutatómunkája során a ghrelin orexigén peptid jutalmazásban betöltött szerepét hangsúlyozta. Vizsgálatai szerint az anorexia nervosa esetén a késleltetett jutalomra való döntéshozatal igazolt, ami alacsony kognitín flexibilitásra utal. Azok az emberek tehát, akiknek alacsony a kognitív flexibilitása, jellemzően a lényegest a lényegtelentől nem azonnal különböztetik meg, mert a figyelem centrumából való váltás, a gátlás nem múködik rögtön. Jobban tudnak diétázni azok, akiknél a késleltetett jutalom melletti döntéshozatal megtalálható $[26,28,33]$. Nézzünk egy példát a megértés kedvéért! Abban kell dönteni, hogy most kell a $40 \mathrm{Ft}$ vagy 30 nap múlva az $50 \mathrm{Ft}$. Tehát várok a többre, a jobbra (az emberek 30\%-a, és az anorexia nervosában szenvedók is így tesznek), vagy inkább a kevesebbet választom, de azt most rögtön kapom meg (az emberek $70 \%$-a).

Megjegyzendő, hogy az anorexia nervosában szenvedôk nem a súlynövekedéstôl, a zsírtól félnek, hanem a fogyást élik meg jutalmul. Érdekesség még, hogy a késleltetett jutalomra való döntéshozatal egyébként a nóknél (9:1) gyakoribb [24, 33].

1. táblázat |Az érzelmi/testi éhség jellegzetességei, elkülönítésük az adott éhségtípust kísérő érzet alapján

\begin{tabular}{l|l|l}
\hline Az adott éhséget kísérő érzet & Testi éhség & Érzelmi/lelki éhség \\
\hline Mikor lép fel? & Több órával az utolsó étkezés után. & Bármikor, hirtelen ötlettől vezérelten. \\
\hline Hol lép fel? & $\begin{array}{l}\text { Mellkas alatt, az epigastriumban, a } \\
\text { gyomortájékon jelentkezó érzés. }\end{array}$ & $\begin{array}{l}\text { Bárhol, jellemzóen gyomorszájtájékon kívüli } \\
\text { érzés. }\end{array}$ \\
\hline Milyen gyakran lép fel? & Naponta maximum két-három alkalommal. & Naponta akár több tízszer is előfordulhat. \\
\hline LEGFONTOSABB jellemzője? & $\begin{array}{l}\text { Lassan fokozódó, az étkezéssel megszúnik, } \\
\text { kellemes teltségérzés váltja fel. }\end{array}$ & Állandó, az étkezéssel is megmarad. \\
\hline Célja? & Jóllakottság. & $\begin{array}{l}\text { Szorongás, melankólia helyett kellemes érzet } \\
\text { kiváltása. }\end{array}$ \\
\hline $\begin{array}{l}\text { Étkezés után milyen hangulatot, közérzetet } \\
\text { biztosít? }\end{array}$ & Kellemes, jó közérzetet ad. & Búntudatot, szégyent kelt. \\
\hline
\end{tabular}




\section{Megbeszélés}

A jelen tanulmány a falásrohamokkal járó evészavarok, a táplálkozási magatartás zavarai mögött kialakuló kövérség és a szükségképpen ezzel együtt járó fogyókúrák és azok kudarcainak a kognitív-viselkedésterápiás összefüggéseit vizsgálta.

Az egyén élete során számos döntése az örökölt és a kondicionált viselkedések eredménye. Így a gyermekek az ételekkel és az evéssel-fogyókúrázással kapcsolatos attitűdjeiket (beállítódásaikat) is „örökölhetik”, ami kognitív tanulásos folyamat, például utánzásos tanulás vagy modellkövetés. Ezt igazolja az a vizsgálat is, miszerint hároméves kor alatti amerikai gyermekek háromszor nagyobb valószínúséggel lesznek elhízottak, ha az egyik szülőjük már az [9]. Az Amerikai Dietetikus Társaság által közzétett adatok szerint, ha bármelyik szülő súlyfölösleggel rendelkezik, akkor 65-75\% valószínúséggel a gyermekük is túlsúlyos lesz [9, 34]. Három-öt éves korra alakulnak ki nagy vonalakban a táplálkozási szokások. Ebben a korai szakaszban jelentős szerepet kap a mintakövetés, a modelltanulás, de fontos a nevelés. Helytelen táplálkozáshoz, elhízáshoz vezethet az is, ha a szülők az étkezést nevelési eszközzé degradálják. Az erre vonatkozó ismereteket - a szerző saját gondolataival kiegészítetten - a 2. táblázat foglalja össze $[4,22]$.

Az anyák fontos szerepet játszhatnak a kulturális értékek átvitelében, így a súly, alak és megjelenés szempontjából is elsőként szolgálnak modellül a lányaik számára $[25,35-37]$.

Az étkezési szokások változásának következő mérföldköve a serdülőkor, az egyik legkedveltebb kutatási téma a táplálkozási magatartás zavarainak kialakulása szempontjából. Bizonyos étkezési minták ebben a korban jellemzők. A tinik gyakran megszokásból bekapnak valamit, vagy éppen hogy kimarad a fótkezés, mert „nincs idő rá”. Viszont cserébe gyakran összeülnek és „rágódnak valamit”, vagy éjszaka „összejönnek és kajolnak egyet”. Mind ez persze rendszertelenné teszi a mindennapok étkezéseit. A környezet által közvetített kockázati tényezők mellett a pszichoszociális hatások (önértékelési zavar, testi elégedetlenség, identitásproblémák) és a hormonális változások is jelentősek $[31,35,36]$. Ostachowska-Gasior és mtsai a lengyel serdülők körében végzett vizsgálataik alapján a reggeliző és nem reggeliző egyének testtömegindex- (BMI-) értékei között nem találtak szignifikáns különbséget, viszont a rendszertelen étkezés, a nassolás, valamint a súlygyarapodás között jelentős összefüggést igazoltak [38]. Ebben a korszakban az ideálok szerepe nagy. Az új ismereteket identifikációval tanulják: a kiválasztott példakép viselkedési mintáit átveszik, ami aztán teljesen beépül, beágyazódik a személyiségbe.

A jelen tanulmány rendszerezetten számot vetett mindazokkal a kognitív viselkedésterápiás ismeretekkel, elvekkel, amelyek az elhízás-fogyás pszichés hátterében előfordulnak.
2. táblázat |Az étel, az étkezés mint nevelési eszköz

\begin{tabular}{|c|c|c|}
\hline & Példák & $\begin{array}{l}\text { Nevelési eszközként } \\
\text { betöltött szerepek }\end{array}$ \\
\hline 1. & $\begin{array}{l}\text { - Akkor kapsz süteményt, ha segítesz } \\
\text { elmosogatni. } \\
\text { - Amíg az ott hagyott maradékot nem } \\
\text { eszed meg, nem kapsz csokit. } \\
\text { - Addig innen nem kelhetsz fel, amíg } \\
\text { meg nem eszel mindent. }\end{array}$ & Büntetés \\
\hline 2. & $\begin{array}{l}\text { - Látod, nem eszed meg ezt a kis sült } \\
\text { husit még, pedig a szomszéd Pistike, } \\
\text { hogy örülne neki! }\end{array}$ & $\begin{array}{l}\text { Bûnösségérzés, } \\
\text { bûntudat keltése }\end{array}$ \\
\hline 3. & $\begin{array}{l}\text { - Megyünk fagyizni, ha hozol egy ötöst } \\
\text { matematikából. } \\
\text { - Fogytál két kilót, ez a kis csoki nem } \\
\text { árthat, megérdemled. }\end{array}$ & Jutalmazás \\
\hline 4. & $\begin{array}{l}\text { - Gyere, edd csak meg ezt a kis sütit, } \\
\text { mindjárt jobban érzed magad! }\end{array}$ & Vigasztalás \\
\hline
\end{tabular}

A fogyókúrák általános buktatói között taglalt a megvonásos és az időhöz kötött terápiák sikertelensége. Czeglédi tapasztalatai szerint mégis konkrét, elérhető, mérhető, reális és időorientált célok kellenek az eredményes diétához. Módszere túlzottan teljesítményorientált, ahol szerinte a páciens maga érveljen a változás mellett, önmotivációs kérdésekkel sarkallja magát a mielőbbi és minél gyorsabb súlycsökkentés érdekében [39]. Ez ellentmondani látszik a Miller-féle elvnek, miszerint a fogyókúra sikerének a lényege az, hogy az egyén folyamatosan változtassa a környezetét, és alakítson ki egészségesebb életmódot, ne pedig a rövid távú sikereket hajszolja [9]. Vegyük észre, hogy ez a Gorwood által leírt késleltetett jutalmazás elméletére cseng rá [33]. Véleményem szerint az erôsen célorientált, teljesítményre sarkalló technikák hosszú távon számos problémát okozhatnak. Nem adnak egyértelmü választ arra, hogy mi történik azokkal a kognitív sémákkal, amiket a céltudatos fogyás elérése érdekében használt az egyén akkor, amikor már a célban van, s nem akar további kilókat leadni. Ugyanis, ha az illető feladja a szigorúan kontrollált fogyást, akkor a jojó szindróma fenyegeti, ha viszont továbbviszi, akkor ez a folyamat könnyen anorexiába torkollhat. Az etiológiai kutatások által igazoltan közismerten magas az anorexia nervosa hátterében a fogyókúrahiba $[5,26,30,40]$.

A fogyókúrák kudarcai mögötti konkrét pszichés tényezők és személyiségjegyek taglalása során látható, hogy a kövérek számos copingstratégiát használnak azért, hogy (például a megbélyegzéssel járó) stresszt, feszültséget redukálhassák. Ennek azonban legtöbbször újabb falatok és további hízás lesz a következménye. A mindennapokban való elfogadtatás nehéz [7]. A stigmákkal való konfrontációban, a pozitív öninstrukciók kidolgozásában, a problémák megoldásában szerepet kaphat az adaptív probléma- és emóciófókuszú megküzdési módok tanulása, a kapcsolatépítő készségek fejlesztése, amely növelheti az egyének együttmúködését a 
súlycsökkentô tréningek során [37, 39]. A kövér populációban ugyanis nem vezethet eredményre sikeres stratégiaként „csak” az empátia úgy, mint más stigmatizált csoportokban (például az AIDS vagy a rákos betegek között) [7, 16, 37].

\section{Következtetés}

A szerző véleménye szerint az a sikeres fogyókúra, ami a gyakorlatban nem az, hanem az étkezési magatartásminták repertoárjában bizonyos nemkívánatos viselkedési elemek tudatos, folyamatos megváltoztatása, illetve elhagyása, valamint az újak beépítése és megtartása, mindezt kis lépésekben, szinte észrevétlenül. Ahol a tanulási folyamatban a megbélyegzés miatti stresszoldás, tehát a "saját magam” és a „saját testem” elfogadása által az önértékelés jobbítása és az életminőség javítása is fontos feladat.

Anyagi támogatás: A közlemény megírása és a hozzá kapcsolódó kutatómunka anyagi támogatásban nem részesült.

A szerző a cikk végleges változatát elolvasta és jóváhagyta.

Érdekeltségek: A szerzőnek nincsenek érdekeltségei.

\section{Irodalom}

[1] Freud, S.: Beyond the pleasure principle. [A halálösztön és az életösztönök.] Múzsák Közmúvelődési Kiadó, Budapest, 1991. [Hungarian]

[2] Chiva, M.: Taste, facial expression and mother-infant interaction in early development. Baroda J. Nutr., 1982, 9(3), 99-102.

[3] Forgács, A.: The psychology of eating. 2nd ed. [Az evés lélektana. 2. kiadás.] Akadémiai Kiadó, Budapest, 2013. [Hungarian]

[4] Birch, L. L., Fisher, J. O.: Mother's child-feeding practices influence daughters' eating and weight. Am. J. Clin. Nutr., 2000, $71(5), 1054-1061$.

[5] Treasure, J., Schmidt, U.: The cognitive-interpersonal maintenance model of anorexia nervosa revisited: a summary of the evidence for cognitive, socio-emotional, and interpersonal predisposing and perpetuating factors. J. Eat. Disord., 2013, 1, 13.

[6] Godart, N. T., Flament, M. F., Perdereau, F., et al.: Comorbidity between eating disorders and anxiety disorders: a review. Int. J. Eat. Disord., 2002, 32(3), 253-270.

[7] Hilbert, A., Ried, J., Zipfel, S., de Zwaan, M.: Stigmatization in obesity. [Stigmatisierung bei Adipositas.] Adipositas, 2013, 7(3), 150-153. [German]

[8] Godart, N. T., Perdereau, F., Rein, Z. et al.: Comorbidity studies of eating disorders and mood disorders. Critical review of the literature. J. Affect. Disord., 2007, 97(1-3), 37-49.

[9] Wansink, B.: Mindless eating. Why we eat more than we think. Random House Publishing Group, New York, 2006.

[10] Resch, M.: Treatment of obesity using a psychosomatic approach. [Az obezitás pszichoszomatikus szemléletű gyógyítása, különös tekintettel a Fluoxetin és a kognitív-behaviorális terápia hatékonyságára.] Kompl. Med., 2001, 5(2), 15-19. [Hungarian]
[11] Perczel-Forintos, D., Mórotz, K.: Cognitive behavioral therapy. [Kognitív viselkedés terápia] Medicina Könyvkiadó, Budapest, 2010. [Hungarian]

[12] Babbie, E.: The practice of social research. [A társadalomtudományi kutatás gyakorlata.] Balassi Kiadó, Budapest, 2008. [Hungarian]

[13] American Psychiatric Association: Diagnostic and statistical manual of mental disorders. 5th ed. DSM-5. American Psychiatric Association, Arlington, 2013.

[14] Fairburn, C. G., Harrison, P. J.: Eating disorders. Lancet, 2003, $361(9355), 407-416$.

[15] American Psychiatric Association: The desk reference to the diagnostic criteria from DSM-5. [DSM-5 referencia-kézikönyv a DSM-5 diagnosztikai kritériumaihoz.] Oriold és Társai Kiadó, Budapest, 2013. [Hungarian]

[16] Resch, M., Sidó Z.: Obesity in a psychosomatic reflection. [Obesitas a pszichoszomatikus tükör előtt.] Lege Artis Med., 1997, 7(12), 802-807. [Hungarian]

[17] Greeno, C. G., Wing, R. R.: A double-blind, placebo-controlled trial of the effect of fluoxetine on dietary intake in overweight women with and without binge-eating disorder. Am. J. Clin. Nutr., 1996, 64(3), 267-273.

[18] Rolls, B. J., Rowe, E. A., Rolls, E. T., et al.: Variety in a meal enhances food intake in man. Psychol. Behav., 1981, 26(2), 215221.

[19] Kahn, B. E., Wansink, B.: The influence of assortment structure on perceived variety and consumption quantities. J. Consum. Res., 2004, 30(4), 519-533.

[20] Resch, M., Szendei, Gy., Haász, P.: Eating disorders from a gynecologic and endocrinologic view: hormonal changes. Fertil. Steril., 2004, 81(4), 1151-1153.

[21] Resch, M., Jákó, P., Sidó, Z., et al.: Psychotherapy and fluoxetine treatment in obesity. [A pszichoterápia és a fluoxetin hatékonysága obesitasban.] Orv. Hetil., 1999, 140(40), 2221-2225. [Hungarian]

[22] Birch, L. L.: Development of food preferences. Annu. Rev. Nutr., 1999, 19(1), 41-62.

[23] Helmering, D. W., Hales, D.: Think, thin, be thin. Broadway Books, New York, 2004, 77.

[24] Garg, N., Wansink, B., Inman, J. J.: The influence of incidental affect of consumer's food intake. J. Market., 2007, 71(1), 194206.

[25] Cassin, S. E., von Ranson, K. M.: Personality and eating disorders: a decade in review. Clin. Psychol. Rev., 2005, 25(7), 895-916.

[26] Hill, A. J., Franklin, J. A.: Mothers, daughters and dieting: investigating the transmission of weight control. Br. J. Clin. Psychol., 1998, 37(1), 3-13.

[27] Decker, J. H., Figner, B., Steinglass, J. E.: On weight and waiting: delay discounting in anorexia nervosa pretreatment and posttreatment. Biol. Psychiatry, 2015, 78(9), 606-614.

[28] Guillaume, S., Gorwood, P., Jollant, F., et al: Impaired decisionmaking in symptomatic anorexia and bulimia nervosa patients: a meta-analysis. Psychol. Med., 2015, 45(16), 3377-3391.

[29] Easter, A., Neumann, U., Northstone, K., et al.: A longitudinal investigation of nutrition and dietary patterns in children of mothers with eating disorders. J. Pediatr., 2013, 163(1), 173178.el.

[30] Marchi, M., Cohen, P.: Early childhood eating behaviors and adolescent eating disorders. J. Am. Acad. Child Adolesc. Psychiatry, 1990, 29(1), 112-117.

[31] Klump, K. L.: Puberty as a critical risk period for eating disorders: a review of human and animal studies. Horm. Behav., 2013, 64(2), 399-410.

[32] Resch., M., Nagy, Á.: Stomatologic complications of the psychosomatic eating disorders. [A pszichoszomatikus evészavarok sztomatológiai szövődményei.] Orv. Hetil., 2012, 153(45), 1779-1786. [Hungarian] 
[33] Gorwood, P., Blanchet-Collet, C., Chartrel, N., et al: New insights in anorexia nervosa. Front. Neurosci., 2016, 10, 256. DOI: 10.3389/fnins.2016.00256, PMCID: PMC4925664

[34] Kirby, J., The American Dietetic Association: Dieting for dummies. 2nd ed. Wiley and Sons, Hoboken, N. J., 2003.

[35] Kotler, L. A., Cohen, P., Davies, M., et al.: Longitudinal relationships between childhood, adolescent, and adult eating disorders. J. Am. Acad. Child Adolesc. Psychiatry, 2001, 40(12), 14341440.

[36] Hilbert, A., Pike, K. M., Goldschmidt, A. B., et al.: Risk factors across the eating disorders. Psychiatry. Res., 2014, 220(1-2), 500-506.

[37] Hilbert, A.: Social and psychosocial effects of obesity. Stigmatization and social discrimination. In: Herpertz, S., de Zwaan, M., Zipfel, S. (eds.): Handbook of eating disorders and obesity. [Soziale und Psychosoziale Auswirkungen der Adipositas. Stigmatizierung und soziale Diskriminierung. In: Herpertz, S., de
Zwaan, M., Zipfel, S. (Hrsg): Handbuch Essstörungen und Adipositas.] Springer, Berlin, 2008, 288-291. [German]

[38] Ostachowska-Gasior, A., Piwowar, M., Kwiatkowski, J., et al.: Breakfast and other meal consumption in adolescents from Southern Poland. Int. J. Environ. Res. Public Health, 2016, 13(5), 453.

[39] Czeglédi, E.: Options of stress management in obesity treatment. [A stresszkezelés alkalmazási lehetőségei az elhízás kezelésében.] Orv. Hetil., 2016, 157(7), 260-267. [Hungarian]

[40] Garner, D. M., Garner, M. V., Rosen, L. W.: Anorexia nervosa "restricters" who purge: implications for subtyping anorexia nervosa. Int. J. Eat. Disord., 1993, 13(2), 171-185.

(Resch Mária dr., Sopron, Mátyás király utca 17. 1/6., 9400 e-mail: reschdr@gmail.com, reschm@freemail.hu)

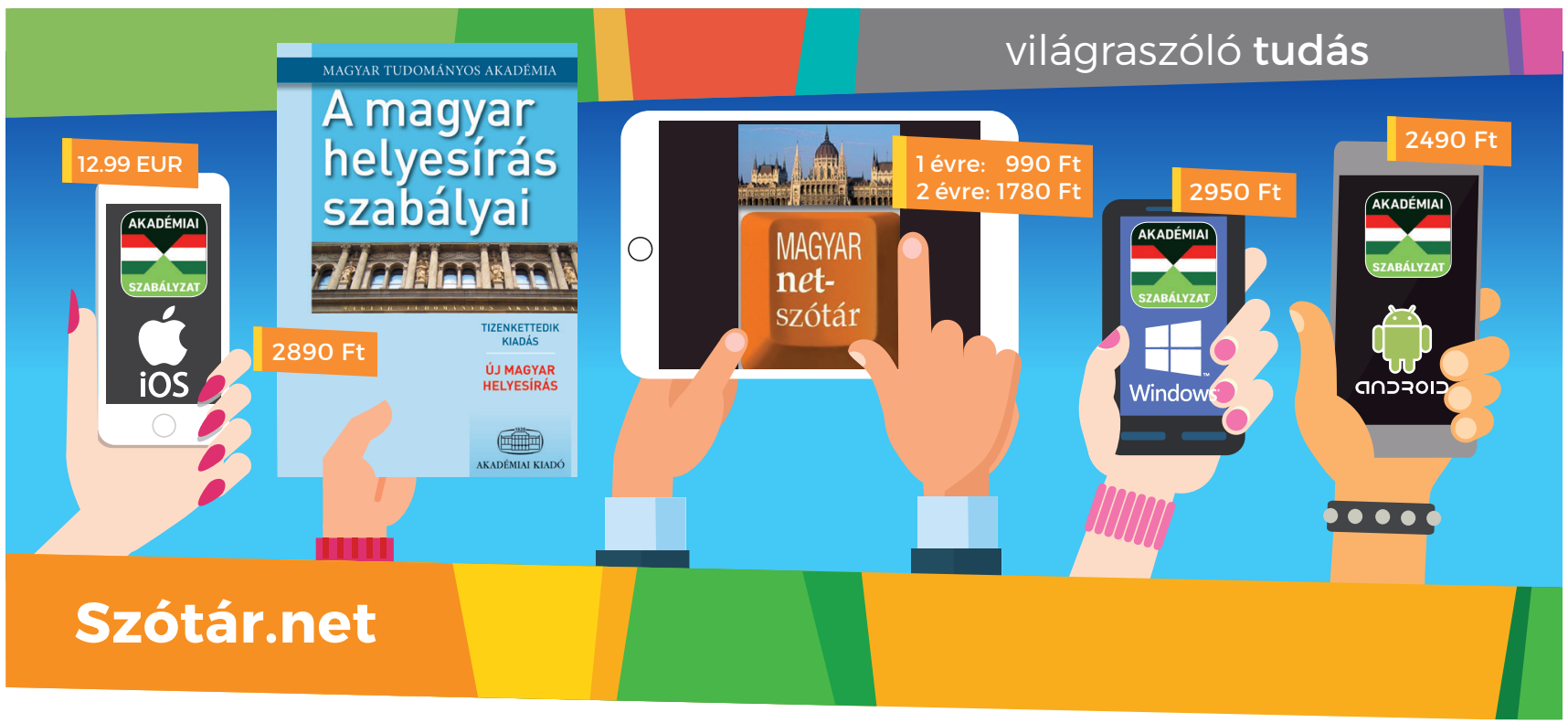

\section{A magyar helyesírás szabályai 12. kiadás}

\section{Mindig a keze ügyében!}

\section{- a Magyar Tudományos Akadémia szabályzata \\ - 300 szabálypont példákkal \\ - szabályzat és szótár egyben

\author{
- a 11. és a 12. kiadás közti különbségek \\ felsorolása, példákkal \\ - tárgymutató
}

Keresse a könyvet a www.akademiai.hu oldalon, vagy válassza az online változatot és a mobilalkalmazást a www.szotar.net-en!

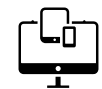

Szótár.net AKADÉMIAI KIADÓ 